\title{
EDUCATIONAL MANAGEMENT IN KINDERGARTEN
}

\author{
Monica-Mihaela BEŞCU 1 \\ DOI: 10.35782/JCPP.2019.1.05
}

\begin{abstract}
The article addresses the issues of educational management in kindergarten and of educational leadership. These two concepts are very important and a lot of researchers are interested to find more information about. We are interested to discover the importance of the activity of a manager in a kindergarten and how this activity influences the quality of education provided there. In the education system in Romania, we have kindergartens that have legal personality and kindergartens that are structures of another kindergarten or another school. Also, there are kindergartens from rural or urban areas. In this article, we propose an approach to the issue of educational management in order to be able to find out to what extent a kindergarten management can influence the work of teachers and all staff in the education unit to achieve quality education.
\end{abstract}

Keywords: leadership, kindergarten in Romania, kindergarten's head-teacher, education management, quality of education, pupils.

\section{Introduction}

This study has started from the increasing importance of the pre-university education management and the educational leadership in recent years, aimed at achieving the success of pre-school education in Romania. There is a need to examine these two concepts, with increasing differences between them. The study is aiming to support preschool educators, including innovative motivational strategies, theories, methods, techniques to reach the set objectives.

The research argument is built on the idea that all school managers need to information about educational management before taking a leadership position in any school or kindergarten. Therefore, they can make quality education in the school unit and can be able to solve the diverse and extensive problems with which face. The need to build a modern, quality education adapted to the educational standards of the European Union states, without failures, without risk, requires a scientific foundation based, specifically on the science of educational leadership and educational management.

Preschool education is the first step of the Romanian education system aimed at developing and educating pre-school children aged between 3 and 6 years according to

1 Drd Prof., Phd at University of Bucharest. E-mail: monica_buzica@yahoo.com 
their physical and psychic development in order to prepare for school and for a successful future in the society. The educators/teachers of kindergarten set the foundation for the education of any child, survey, observe and understand how it grows and evolves, being constantly changing in a modern world.

The interdisciplinary approach to content is a necessity given by the preschooler's need to know and explore the environment. This is also the career status that defines and motivates my efforts. Experience as a kindergarten manager has allowed me to observe pre-school education, becoming increasingly interested in the influence of the kindergarten head-teacher in terms of achieving performance to the expected standards.

This study will synthesize the original personal contributions to the development of educational management and educational leadership in pre-school education institutions, to the enhancement of the quality of the educational process, to the development and maintenance of a close collaboration with the local family and community. We will reflect on the evolution of leadership on national and international level, analyzing the current situation in kindergartens regarding the concrete activity of the managers and aiming at making them more efficient.

From my practice I have observed that successful educational management largely depends on the motivation of all factors involved in education, so the proposed targets will pursue its real growth and the development of innovative and motivational strategies. Also, the necessary information on the training, selection and evaluation of kindergarten managers as well as of school or high school managers, which are referred to as kindergarten structures, will be made available for the achievement of an efficient educational management. Thus, solutions will be identified to improve management in preschool education so that pre-school children can be educated in such a way that you can look with joy and pride in the eyes of the adult who will become.

As a result of the research we will find the degree of satisfaction of the parents and the local community regarding: the activity in the kindergarten, the real progress of the preschools, the conduct and the level of involvement of the directors and the whole staff in the kindergarten, the training and the improvement, to permanent change. We will observe the evolution of managers in rural and urban education, the differences between the quality of education made in kindergartens with legal personality, or that have included all kindergartens and kindergartens that are structures of secondary schools or high schools. As a result, we will identify the factors that influence and condition the achievement of a high-performance education and we will propose a continuous training program to increase performance to support educational leadership.

\section{The educational management in kindergarten}

Kindergarten has an important role in building the foundation of the entire child's education in order to develop its personality. In the years spent in kindergarten, the preschool accumulates and acquires the knowledge and skills necessary to prepare him / her for school but also for integrating into society, helping him / her throughout the educational process. 
An educational institution with legal personality is led by a manager. (Romanian Education Low 1/2011). Educational management is the area that reflects leadership activity in an educational institution and which refers to the functioning and management of educational units.

Bolam analyzes this area and defines it as "an executive function designed to implement approved policies" (Bush, 2015, p. 13). Also, Bolam proposes to make a distinction between educational management and educational leadership. From a different perspective, Sapre argues that "management involves a series of activities oriented towards efficient and effective use of organizational resources to achieve organizational objectives" (Sapre, 2002, p. 102). We agree with the ideea that "management must be mindful of the purpose and objectives of education" (Bush, 2015, p. 13). This, of course, has sparked the existence of many opposing views. However, it is argued that management activities and tasks must somehow be permanently linked to the objectives and objectives of educational institutions. Despite numerous debates and disagreements in the literature, this is a primordial principle without which quality education can not be achieved.(authors like Bush, Sapre, Bolam). Of course objectives and objectives give us important milestones to support the management of an educational establishment. Educational management aims to achieve certain educational objectives and strategic objectives, which a manager and determines according to many factors. If there is no clear, stable and logical link between purpose, objectives and management, malfunctions occur, different dangers of downtime, including the transition to "managerialism", with a "focus on procedures to the detriment of educational objectives and values". (Bush, 2015, p.13).

There is a clear need to put this on educational purpose. But we ask ourselves: are all the objectives set up? The answers can be multiple, but we firmly support the fact that it is clear from practice that not always the objectives set and pursued by a manager have proved to be the most appropriate. Increased attention should therefore be paid to setting the targets and objectives to be achieved. Often they are imposed outside the school, which negatively influences the activity of an educational unit. These objectives, imposed, may or may not meet the needs of an educational institution, pre-school needs or even the needs of teachers and all employees.

It is fundamental that management is geared to achieving certain educational objectives, but we must also keep in mind that they are also agreed upon by the respective institution and the community. A lot of researchers (Furlong, Wright, Bush etc.) consider that if a manager follows the implementation of external initiatives, without having specific interventions, tailored objectives and adapted to the institution he is leading, he risks limiting and slipping towards managerialism.

Most theoretical approaches, emphasisse the importance of objectives and the management goals for an educational institution. However, there are also disagreements on some issues. Here are some questions that arise from these disagreements:

1. Formal objectives. What value do they have?;

2. Organizational or individual objectives. What do we support? / What do we promote ?; 
3. Objectives, institutional objectives or other curricular elements specific to the field. How are they established? What criteria are the basis for action?

Gunter makes a history of the syntagms that have been used to define this complex and important field, which has varied from "educational administration" to "educational management" and, recently, to "educational leadership" (Bush, 2015, p.17). This change is illustrated in England by the establishment of the National College for School Leadership in 2000.

Yukl states that there are several definitions of leadership some more useful than others, not to say that there is only a correct definition. (Yukl, 2002, p.4-5). Cuban also offers a clear differentiation between the two concepts: leadership and educational management. Moreover, he succeeds in identifying the importance of both dimensions: ( Bush, 2015, p. 21). "By leadership I mean influencing the actions of others to achieve desirable results. Leaders are those people who outline the purposes, motivation, and actions of others. Often, they initiate change to achieve either existing objectives or new objectives. Leadership requires much ingenuity, energy and talent" (apud Bush, 2015, p. 21). "Management implies maintaining the efficiency of the organization's current activities. Although management often requires leadership skills, its global function is to maintain and not to change. They value both management and leadership, without benefiting anyone, since the different contexts require responses" (apud Bush, 2015, p. 21).

The concept of quality in education is a system of essential features of the learning process that, due to changes generated by evolution, favors the emergence of other phenomena superior to the first. In the literature, we identify a set of management models: "Cuthbert sets five categories of management models" (Bush, 2015, p.48): 1. Analytical and rational; 2. Pragmatic-rational; 3. The policy; 4. Models that highlight ambiguity; 5. Phenomenologically; 6. Interactionist.

Tony Bush identifies six key educational management models detailed in his book in 2015: a. Formal; b. College; c. Political; d. Subjective e. Ambiguity; f. Cultural;

Also, within the literature, Bush and Glover identified 10 leadership models that are associated with the six previously identified Bush management models:

- Management formal - managerial leadership;

- Collective management - participatory, transformational, distributed;

- Political management - transactional leadership;

- Subjective management - postmodern, emotional leadership;

- Management of ambiguity - circumstantial leadership;

- Management culture-moral leadership, training;

According to Davies, there are seven categories of leadership: i. Strategic Leadership; ii. Invitation Leadership; iii. Ethical Leadership; iv. Constructivist Leadership; v. Poetic and political leadership; vi. Leadership entrepreneurial; vii. Sustainable Leadership. 
Both preschools, teachers and managers are constantly changing. The organization acquires a new form of the entity by realizing innovation at its level. Innovative motivational strategies are nothing more than a system of methods, processes, means and organizational forms used to achieve quality in education. Leadership and effective educational management are essential to a performance in an educational organization. Their models are of particular importance to all members of the educational institution, as they are models to follow for everyone else. Thus, the importance of management and leadership in education institutions for qualitative education is obvious.

\section{Pre-school education in Romania}

German pedagogue Froebel (1782-1852) was interested in the importance of the early years of the child's life and was the one who founded the first kindergarten in Blankenburg in 1837. The institution then appears in Romania in 1909, during Spiru Haret ministry (1851-1912).

"The education system is the main subsystem of the education system. In Romania, education system includes: pre-school education, primary education, lower secondary education, general compulsory education, upper secondary education, arts and crafts schools, apprentice schools, post-high school education and higher education." (Romanian National Education Law no. 1/2011). The structure of the school year, including course sessions, holiday periods and national exams, shall be established by order of the Minister for National Education. School classes can be suspended for a certain period of time, in emergency situations, in case of epidemics, natural calamities, diseases or crisis situations. Authorized educational institutions (accredited) are part of the national school network, which is constituted annually in accordance with the provisions of the law in force. (Romanian National Education Law no. 1/2011).

The Education Law no. 84/1995 provided for the gradual generalization of the preparatory group for the school so that the enrollment rate of the children in the kindergarten increased annually. The year 2000 brought a new vision of preschool education, seen within the educational program "Organization of pre-primary education", and in 2002 the program "Generalization of the large preparatory group in the pre-school education in Romania" was initiated. During 2005-2006, the Strategy of the Ministry of Education and Research in the field of Early Education was developed with the support of UNICEF. The Law of National Education 1/2011 places the preparatory class at school. Pre-school education includes children aged between 3 years and 6-7 years. Activities take place in regular, extended or weekly kindergartens. Preschool education is structured on two levels: level I that prioritises the socialization of children aged between 3 and 5 years and level II that aims to prepare for schooling children aged 5 to 6 years. The Law of National Education 1/2011, with its subsequent amendments and completions, is the law governing the current education. Early education - pre-school education includes small, middle and large group. At each community level, there is a school network that includes all the institutions in that locality, specifying the status of each. This school network is established by the Local Council Decision at the beginning of each budget year and refers to the next school year. This establishes the institutions 
with legal personality and those that become structures and are attached to an institution with legal personality.

The school and the community are two realities that represent an interest for: pedagogues, sociologists, psychologists, philosophers, anthropologists, etc., each trying to capture the issues that contribute to their operating mechanisms, also the involved agents and the degree of involvement in promoting education. (Staiculescu, 2011, p.24)

In Romania, only pre-university education unit with legal personality cand have a manager. To have legal personality (PJ), according Education Law no.1/2011, a kindergarten must have certain elements: a) act of establishment; b) possesses heritage, whether as public / private property or through administration / convenience / rental; c) fiscal identity code (CIF); d) account in the Treasury of the State; e) stamp with the coat of arms of Romania, with the current name of the Ministry of National Education and with the exact name of the educational unit.

Each legal entity has a leadership, staffing and budget, performs financial statements and, according to the law of institutional and decision-making autonomy, within certain limits. On the other hand, a unit of education without legal personality, which is subordinated to another educational institution, which has legal personality, is called structure of that unit. (Romanian National Education Law no. 1/2011). In order to have legal personality, a kindergarten must have at least 150 preschools, according to the mentioned law.

Pre-primary education institutions may have only legal personality or may have one or more kindergartens as a structure. However, there are also cases where a kindergarten has no legal personality and is considered as a secondary school or high school structure. In order to facilitate the enrollment of children in education at any level, after consultation with the local public administration and with the educational units, the county school inspectorates establish, for each educational unit, the school constituencies of the educational units. School districts are established for educational establishments that preschool pre-school, elementary and lower secondary classes, in compliance with the provisions of the law in force. This is made up of the streets near the school and is thus allocated to it, for enrolling in preschool / pupils living at addresses located on these streets. After setting up the school districts, the educational establishments are obliged to make the census of the children annually.

In Romania, there is a concurrent environment in terms of the network of educational units. There are several categories of institutions. From the most prestigious to the least prestigious. These are ranked in this ranking based on the results and performance recorded. On the other hand, we can see that an important role in the choice of the kindergarten by the parents is the location of the kindergarten, the configuration of the building, its facilities and the opportunities it offers. Another motivating factor that plays an important role is of course the educator. Parents are interested long before enrolling their child in the kindergarten by their educator. The most common question nowadays is: what educators do I enroll for my child? After a thorough analysis of the educator's work, the level of training, the activities that both school and extra-curricular activities take, after discussions with the parents of preschoolers who graduated from 
the kindergarten and are enrolled in that teacher, the parent chooses the educator. There are many cases where an educator is more demanded than other colleagues. These situations can be considered as a plus because it is good for an educator to be desirable for her qualities, her parents, but on the other hand, in such frequent situations, it is necessary to take action. Because my experience like manager and like teacher I can oserv this practices in my kindergarten and in anothers kindergartens.

\section{A possibile design of research in educational management}

The research will provide the necessary information on the training, selection and evaluation of kindergarten managers as well as of school or high school managers who have a kindergarten structure to achieve an effective educational management. Thus, solutions will be identified to improve management in preschool education so that preschool children are educated in such a way as to become mature adults adapted and integrated into the society in which they live.

Thereffore, the aim of the research would be to propose new methods and practices in managerial activity. Also, we propose several objectives and hypotheses. Some of the hypotheses could be:

I1. If the kindergarten ensures the quality of the educational process in the kindergarten then the pre-school children will be prepared for the school.

I2. If the manager has leadership skills and offers teachers positive conditions and motivations, then the teaching staff will provide pre-school opportunities for personality development at a high level.

I3. If the parents, the local community, the manager and the teaching staff are prepared to properly assess the work of the actors involved, the education will be a qualitative one.

I4. If the kindergarten develops a fair and real partnership with parents and the community, then the quality of the vertical and horizontal relationships will increase, the child will have greater flexibility in assimilating new knowledge.

Therefore, in the proposed research, we will have the following independent variables: the type of staff and the director; age of staff and director (EE); professional status of teachers; teacher experience; teaching degree; environment of origin - rural or urban;

Methods, techniques and tools for collecting, analyzing and interpreting research data

- Quantitative methods: questionnaire, statistical data collection methods, interview,

- Qualitative methods: observation, content analysis of school documents, case study, reflective journal, focus group

We shall have results that will help us to identify issues related to educational management. 


\section{Conclusions}

In this research, we propose an approach to the issue of educational management in order to be able to find out to what extent a kindergarten management can influence the work of teachers and all staff in the education unit to achieve quality education.

\section{References}

Bolam, R. (1999). Educational administration, leadreship and management: towards a research agenda, in T. Bush, L. Bell, R. Bolam, R. Glatter şi P.Ribbins (eds.), Educational Management: redefining Theorz, Policz and Practice. Londra: Paul Chapman Publishing.

Bush, T. (2015). Leadership și management educațional. Teorii și practici actuale. Iași: Polirom.

Sapre, P. (2002).Realising the potential of educational management in India, Educational Management and Administration, 30 (1): 101-108.

Staiculescu, C. (2011). School in local community context-Case study-Puiesti Village, Buzau County- Journal of Community Positive Practices, 3(2011), 23-68.

Yukl, G.A. (2002). Leadership in Organizations, V edition, Upper Saddle River, NJ: PrenticeHall.

*** Romanian National Education Law no. 1/2011. 